\title{
Macroalgal responses to experimental nutrient enrichment in shallow coastal waters: growth, internal nutrient pools, and isotopic signatures
}

\author{
Mirta Teichberg ${ }^{1,2, *}$, Sophia E. Fox ${ }^{3}$, Carolina Aguila ${ }^{1}$, Ylva S. Olsen ${ }^{3}$, Ivan Valiela ${ }^{3}$ \\ ${ }^{1}$ Boston University Marine Program, Marine Biological Laboratory, 7 MBL Street, Woods Hole, Massachusetts 02543, USA \\ ${ }^{2}$ Center for Tropical Marine Ecology, Fahrenheitstrasse 6, 28359 Bremen, Germany \\ ${ }^{3}$ The Ecosystems Center, Marine Biological Laboratory, 7 MBL Street, Woods Hole, Massachusetts 02543, USA
}

\begin{abstract}
Increased nutrient inputs to temperate coastal waters have led to increased occurrences of macroalgal blooms worldwide. To identify nutrients that are limiting to macroalgae and to determine whether different forms of these nutrients and long-term ambient nutrient conditions affect macroalgal response, we used in situ enrichment methods and tested the response of 2 bloom-forming species of macroalgae, Ulva lactuca and Gracilaria tikvahiae, from shallow estuaries of Waquoit Bay, Massachusetts, USA, that receive different land-derived N inputs. We enriched caged macroalgal fronds with nitrate, ammonium, phosphate, and N + P combinations, and measured growth, nutrient content, and $\delta^{15} \mathrm{~N}$ signatures of fronds after $2 \mathrm{wk}$ of incubation. In these estuaries, P did not limit growth, however, the 2 species differed in growth response to $\mathrm{N}$ additions. Growth of U. lactuca was greater in Childs River (CR), the estuary with higher nitrate inputs, than in Sage Lot Pond (SLP); growth in SLP increased with nitrate and ammonium enrichment. In contrast, growth of G. tikvahiae was greater in SLP than in CR, but had no growth response to $\mathrm{N}$ enrichment in either site. C and $\mathrm{N}$ contents differed initially between species and sites, and after nutrient enrichment. Final tissue \% N increased and C:N decreased after nitrate and ammonium enrichment. $\delta^{15} \mathrm{~N}$ values of the macroalgae demonstrated uptake of the experimental fertilizers, and a higher affinity and faster turnover of internal $\mathrm{N}$ pools with ammonium than nitrate enrichment in both species. We suggest that $U$. lactuca blooms in areas with both high nitrate and ammonium water column concentrations, and is more N-limited in oligotrophic waters where DIN levels are too low to sustain high growth rates. G. tikvahiae has a greater $\mathrm{N}$ storage capacity than $U$. lactuca, which may allow it to grow in less nutrientrich waters.
\end{abstract}

KEY WORDS: Macroalgal blooms - Eutrophication - Nutrient limitation $\cdot \mathrm{N}$ uptake $\cdot$ Assimilation · Ulva spp. · Gracilaria spp. $\cdot$ Nitrate $\cdot$ Ammonium $\cdot$ Phosphate

\section{INTRODUCTION}

In temperate coastal waters, $\mathrm{N}$ is the most common nutrient limiting primary production (Ryther \& Dunstan 1971, Nixon \& Pilson 1983, Howarth 1988). Increases in $\mathrm{N}$ inputs to coastal waters have increased primary production, shifted composition of primary producers (Duarte 1995), and created more frequent macroalgal blooms (Sfriso et al. 1992, Valiela et al. 1992, 1997a, Rafaelli et al. 1998, Morand \& Merceron 2005). In some cases, however, growth of macroalgae may be P-limited during certain periods of the year (Peckol et al. 1994). P is often limiting in carbonate-rich systems more commonly associated with tropical environments (Lapointe et al. 1992).

The main sources of anthropogenic dissolved inorganic $\mathrm{N}$ (including $\mathrm{NO}_{3}^{-}$) to coastal systems are atmospheric deposition, fertilizer use, and wastewater disposal (Valiela et al. 1997b, Howarth et al. 2002). Most cases of increasing trends in $\mathrm{N}$ loads over recent decades have been attributed to elevated $\mathrm{NO}_{3}{ }^{-}$inputs to coastal waters (Cloern 2001, Howarth et al. 2002), 
which are largely responsible for increases in the occurrence of macroalgal blooms (Sfriso et al. 1992, Valiela et al. 1992, Cloern 2001, Fox et al. 2008). $\mathrm{NH}_{4}{ }^{+}$ inputs from raw sewage, aquaculture activities, and dissolved organic nitrogen from benthic nutrient regeneration are increasingly more common, and also support macroalgal production (Trimmer et al. 2000, Tyler et al. 2001, Sundback et al. 2003, Barile 2004, Lapointe et al. 2005a,b, Tsai et al. 2005).

The effect of increased nutrient availability on macroalgal growth and bloom occurrences are influenced by various factors. Morphology may play a large role in macroalgal response to nutrients, as functional form has been found to impact algal nutrient requirements, uptake kinetics, and storage capacity (DeBoer et al. 1978, D'Elia \& DeBoer 1978, Littler \& Littler 1980, Fujita 1985, Duke et al. 1989, Pedersen \& Borum 1996). In enrichment experiments, uptake of dissolved inorganic nitrogen (DIN) is directly reflected by increased growth rate in Ulva lactuca and other species that have high $\mathrm{N}$ requirements, but less so for species with low N requirements, high storage capacity, or slow growth rates (Lapointe 1981, Fujita 1985, Pedersen \& Borum 1996, Fong et al. 2004). Gracilaria spp. have higher nutrient storage capacity that can be used to support growth for up to 2 wk under low nutrient conditions (Lapointe 1981, Fujita 1985). The additive effect of long-term ambient high or low nutrient conditions on macroalgae may therefore play roles in their responses (D'Elia \& DeBoer 1978, Fujita 1985, Peckol et al. 1994, Fong et al. 2003).

Macroalgae take up $\mathrm{NH}_{4}{ }^{+}$more readily than $\mathrm{NO}_{3}{ }^{-}$ (D'Elia \& DeBoer 1978, Pedersen \& Borum 1997, Naldi \& Wheeler 2002, Runcie et al. 2003, Cohen \& Fong 2004) because $\mathrm{NH}_{4}{ }^{+}$is a reduced form of $\mathrm{N}$ requiring less energy for uptake. There are differences in the physiological processes involved in uptake of $\mathrm{NO}_{3}{ }^{-}$ and $\mathrm{NH}_{4}{ }^{+}$, however, and macroalgae may differ in their preference or uptake ability and storage of these nutrients (DeBoer et al. 1978, Pedersen \& Borum 1997, Naldi \& Wheeler 2002). Some bloom-forming seaweeds such as Ulva spp. take up both forms of N (Naldi \& Wheeler 2002, Cohen \& Fong 2004) at similar rates, while others (including Gracilaria spp.) have higher affinity for $\mathrm{NH}_{4}{ }^{+}$(DeBoer et al. 1978, Naldi \& Wheeler 2002). The ability to take up $\mathrm{NO}_{3}{ }^{-}$may depend on the level of nitrate reductase activity in the algae (Lartigue \& Sherman 2005, Teichberg et al. 2007). In another study, we found nitrate reductase activity to be significantly lower in G. tikvahiae than in U. lactuca (M. Teichberg unpubl. data), indicating that G. tikvahiae may have a longer lag time than $U$. lactuca between $\mathrm{NO}_{3}{ }^{-}$uptake and reduction to $\mathrm{NH}_{4}{ }^{+}$, which then is used for synthesis of amino acids and growth.

Stable nitrogen isotope techniques have been used to assess macroalgal $\mathrm{N}$ uptake and assimilation in fer- tilization experiments (Naldi \& Wheeler 2002, Cohen \& Fong 2004, Lepoint et al. 2004) and to identify the sources of $\mathrm{N}$ utilized by the algae from land-derived inputs such as wastewater (McClelland \& Valiela 1998, Lapointe et al. 2005a,b). The $\delta^{15} \mathrm{~N}$ signatures of algae may change relatively quickly, as $\mathrm{N}$ sources change with little fractionation (Deutsch \& Voss 2006), making it possible to use $\delta^{15} \mathrm{~N}$ values of fast growing macroalgae as a measure of their $\mathrm{N}$ uptake and assimilation of different sources of N (Deutsch \& Voss 2006). Taxonspecific differences in rates of uptake and turnover of $\mathrm{N}$ and growth, however, may mediate rates of $\delta^{15} \mathrm{~N}$ changes in the presence of a new $\mathrm{N}$ supply (Deutsch \& Voss 2006).

To identify nutrients that effectively control growth in different macroalgal taxa, we assessed responses of the common green and red bloom-forming species Ulva lactuca and Gracilaria tikvahiae to short-term enrichment with $\mathrm{NO}_{3}{ }^{-}, \mathrm{NH}_{4}{ }^{+}$, and $\mathrm{PO}_{4}{ }^{3-}$. To determine whether previous exposure history to different nutrient regimes results in different algal responses to the supply of $\mathrm{NO}_{3}{ }^{-}, \mathrm{NH}_{4}{ }^{+}$, or $\mathrm{PO}_{4}{ }^{3-}$, we assessed intraspecific growth response differences in fronds collected from waters with different long-term ambient nutrient regimes. We hypothesized that nutrient assimilation differs among thalli with different nutrient histories, which may impact growth and bloom frequencies in coastal shallow waters. In these experiments we measured frond growth rates, internal $\mathrm{N}$ and $\mathrm{C}$ content, and $\mathrm{N}$ stable isotope ratios to assess differences in $\mathrm{NO}_{3}{ }^{-}$and $\mathrm{NH}_{4}{ }^{+}$assimilation.

We carried out experiments in the Waquoit Bay estuarine system because the sub-estuaries receive different $\mathrm{N}$ inputs from their watersheds, and thus, differ in ambient N concentrations (Valiela et al. 1992, 1997b). Childs River (CR) is an urbanized watershed receiving a high $\mathrm{N}$ load from wastewater inputs, and the $\mathrm{N}$ is mainly in the $\mathrm{NO}_{3}{ }^{-}$form. Sage Lot Pond (SLP) is a forested watershed receiving a low $\mathrm{N}$ load, with $\mathrm{NH}_{4}{ }^{+}$ as the dominant DIN form (Valiela et al. 1997b). Annual mean $\mathrm{CR}$ water column $\mathrm{NO}_{3}{ }^{-}$concentrations (in the salinity range 20 to $30 \mathrm{ppt}$ ) are much higher than in SLP (approximately 14 and $0.5 \mu \mathrm{M}$, respectively, Holmes 2008). Annual mean water column concentrations of $\mathrm{NH}_{4}{ }^{+}$in CR and SLP are similar (approximately $1 \mu \mathrm{M}$ ), although $\mathrm{NH}_{4}{ }^{+}$concentrations in the summer often reach much higher concentrations in SLP (M. Teichberg unpubl. data) when mineralization rates of organic matter are high. There are several dominant macroalgal species in Waquoit Bay, including Cladophora vagabunda, Ulva lactuca, and Gracilaria tikvahiae (Fox 2008, Fox et al. 2008). Macroalgal biomasses in the two estuaries differ, with a higher overall biomass in CR (180 g dry weight [dry wt] $\mathrm{m}^{-2}$ in CR and $45 \mathrm{~g}$ dry wt $\mathrm{m}^{-2}$ in SLP, Fox 2008); the biomass proportions of 
different seaweed species also differ (Fox 2008). Annual biomasses of U. lactuca and G. tikvahiae are both high in $\mathrm{CR}$, but $U$. lactuca reaches a higher maximum biomass during the summer (510 $\mathrm{g}$ dry wt $\left.\mathrm{m}^{-2}\right)$ than G. tikvahiae (290 $\mathrm{g}$ dry wt $\mathrm{m}^{-2}$ ) (Fox 2008). In contrast, G. tikvahiae in SLP reaches a maximum biomass of $190 \mathrm{~g}$ dry wt $\mathrm{m}^{-2}$, whereas $U$. lactuca has a much lower biomass of $2 \mathrm{~g}$ dry wt $\mathrm{m}^{-2}$ (Fox 2008). Therefore, the Waquoit Bay estuarine system serves as a good model to compare the responses of bloom-forming macroalgae with different relative biomasses and nutrient histories to increased nutrient enrichment in shallow temperate estuaries.

\section{MATERIALS AND METHODS}

Experimental unit and design. Fronds of Ulva lactuca and Gracilaria tikvahiae were collected along the banks of CR and SLP in Waquoit Bay on 5 July and 6 July 2005, and incubated in Plexiglas ${ }^{\mathrm{TM}}$ cages for $13 \mathrm{~d}$ in their estuaries of origin. Each cage contained several fronds of each species, totaling approximately $2 \mathrm{~g}$ wet wt of U. lactuca and $5 \mathrm{~g}$ wet wt of G. tikvahiae. These biomasses were chosen to minimize competition for nutrients and the effects of caging. The cage dimensions were $20 \times 20 \times 15 \mathrm{~cm}$ with 2 sides of $1 \mathrm{~mm}$ mesh to exclude grazers while allowing water through-flow. Cages were attached $3 \mathrm{~m}$ apart to an anchored line, $2 \mathrm{~m}$ from shore, and suspended within the macroalgal canopy 0.1 to $0.3 \mathrm{~m}$ above the sediment depending on the tide, and kept upright with buoys. Water depth ranged between 0.5 and $1.5 \mathrm{~m}$, with an average tidal range of $0.5 \mathrm{~m}$. Cages were submerged at all times and were attached so that they would freely turn with their mesh side facing the direction of the tidal flow.

To ascertain whether growth was $\mathrm{N}$ or P limited, and whether there were differences in responses to $\mathrm{NO}_{3}{ }^{-}$ and $\mathrm{NH}_{4}{ }^{+}$, we applied the following nutrient treatments, with 4 replicates per treatment: additions of (1) $\mathrm{NO}_{3}{ }^{-}$, (2) $\mathrm{NH}_{4}{ }^{+}$, (3) $\mathrm{PO}_{4}{ }^{3-}$, (4) $\mathrm{NO}_{3}{ }^{-}+\mathrm{PO}_{4}{ }^{3-}$, (5) $\mathrm{NH}_{4}{ }^{+}+$ $\mathrm{PO}_{4}{ }^{3-},(6)$ no additions (controls). To deliver the nutrients to the algae in each cage, we installed perforated PVC-plastic tubes fixed upright in the centers of the cages and filled with either $2 \mathrm{M} \mathrm{KNO}_{3}, 2 \mathrm{M} \mathrm{NH}_{4} \mathrm{Cl}, 1 \mathrm{M}$ $\mathrm{KH}_{2} \mathrm{PO}_{4}, 2 \mathrm{M} \mathrm{KNO}_{3}+1 \mathrm{M} \mathrm{KH}_{2} \mathrm{PO}_{4}$, or $2 \mathrm{M} \mathrm{NH}_{4} \mathrm{Cl}+1$ $\mathrm{M} \mathrm{KH}_{2} \mathrm{PO}_{4}$ dissolved in a $3 \%$ agar solution. Control cages contained empty PVC tubes. This arrangement allowed the nutrients to slowly and continually leak out of the PVC tubes and into the cage throughout the incubation period. We tested this nutrient delivery method and others from Worm et al. (2000), and found the agar tube was the most effective at maintaining concentrations of nutrients within the cages.
Nutrient concentrations in experimental cages and ambient water. To ascertain whether the experimental nutrient additions were efficacious, and to quantify differences in ambient nutrient concentrations between the 2 estuaries, we sampled water within the experimental cages and in the surrounding ambient water on 4 different days throughout the experiment. We collected $50 \mathrm{ml}$ of water from each cage using a syringe that 'sipped' water through polyethylene tubes $(0.3 \mathrm{~cm}$ diameter) extending from the surface of the water to the inside of the cage. Ambient water samples were taken from the water column located at either end of the line of cages. All samples were filtered through a glass microfiber GF/F filter, and frozen until analysis at the end of the experiment. $\mathrm{NO}_{3}{ }^{-}, \mathrm{NH}_{4}{ }^{+}$, and $\mathrm{PO}_{4}{ }^{3-}$ concentrations were measured in all water samples using standard colorimetric methods on a Lachat Autoanalyzer (QuickChem FIA+ 8000 Series). To evaluate any differences in ambient environmental conditions between the 2 sites, we measured ambient temperature, salinity, and light throughout the incubation period using a YSI 85 probe and a LICOR 1000 quanta meter at each of our sites near the experimental deployments. Dissolved oxygen data from the National Oceanographic and Atmospheric Administration, Waquoit Bay National Estuarine Research Reserve (NERR) at these two sites were averaged to get monthly means for July 2005.

Macroalgal growth, internal nutrient content and $\delta^{15} \mathrm{~N}$ response to nutrient enrichment. To measure macroalgal growth response to nutrient treatment, we recorded initial and final wet mass of the set of fronds within each cage. Algal fronds were individually blotted with paper towel prior to weighing. Approximately 3 to 4 fronds of each species were placed in each cage. After $13 \mathrm{~d}$ of incubation, specific growth rates $(\mu)$ were calculated as a percentage increase in biomass per day $\left(\% \mathrm{~d}^{-1}\right)$ :

$$
\mu=\frac{100\left[\operatorname{Ln}\left(N_{t} / N_{\mathrm{o}}\right)\right]}{t}
$$

where $N_{t}$ is biomass on day $t, N_{\mathrm{o}}$ is the initial biomass, and $t$ is time in days of incubation (Lobban \& Harrison 1994).

To determine whether ambient nutrient supply and experimental nutrient enrichment affected internal nutrient content of the macroalgae, we measured initial and final $\mathrm{N}$ and $\mathrm{C}$ contents of experimental fronds. Macroalgal tissue was cleaned with deionized water and dried at $60^{\circ} \mathrm{C}$ in a drying oven, ground to a fine powder, and measured on a CHN elemental analyzer. Ancillary experiments with open cages (cage with one mesh side missing) were carried out to test whether \% tissue $\mathrm{N}$ of the fronds was affected by reduced flow in the cage. 
To corroborate evidence for macroalgal uptake of experimentally provided nutrients and to track changes in macroalgal $\mathrm{N}$ uptake and assimilation under the different treatments, we used stable $\mathrm{N}$ isotope methodology. Macroalgal tissue for isotope analysis was prepared as described for analysis of internal nutrient contents. Dried and ground samples of tissue were sent for stable $\mathrm{N}$ isotope analysis on a mass spectrometer at the Stable Isotope Facility of the University of California at Davis, CA, USA. Results are reported in comparison with atmospheric nitrogen as a standard and calculated as:

$\delta^{15} \mathrm{~N}(\%)=[(\mathrm{R}$ sample $-\mathrm{R}$ standard $) / \mathrm{R}$ standard $] \times 10^{3}$ where $\mathrm{R}$ is ${ }^{15} \mathrm{~N} /{ }^{14} \mathrm{~N}$. Duplicate determinations on the same sample usually differed by $<0.2 \%$.

Statistical analyses. To evaluate differences in water nutrient concentrations by nutrient treatment and across the incubation period, we ran a repeated measures ANOVA with time as the within-subject factor and nutrient treatment as the between-subject factor for $\mathrm{NO}_{3}{ }^{-}, \mathrm{NH}_{4}{ }^{+}$, and $\mathrm{PO}_{4}{ }^{3-}$ concentrations in each site (SPSS 11). Macroalgal growth and final tissue nutrient content in response to nutrient treatment were analyzed using a nested ANOVA with nutrient treatment nested in site, and using a post-hoc Tukey test to determine pairwise differences between nutrient treatments (Statistica 7).

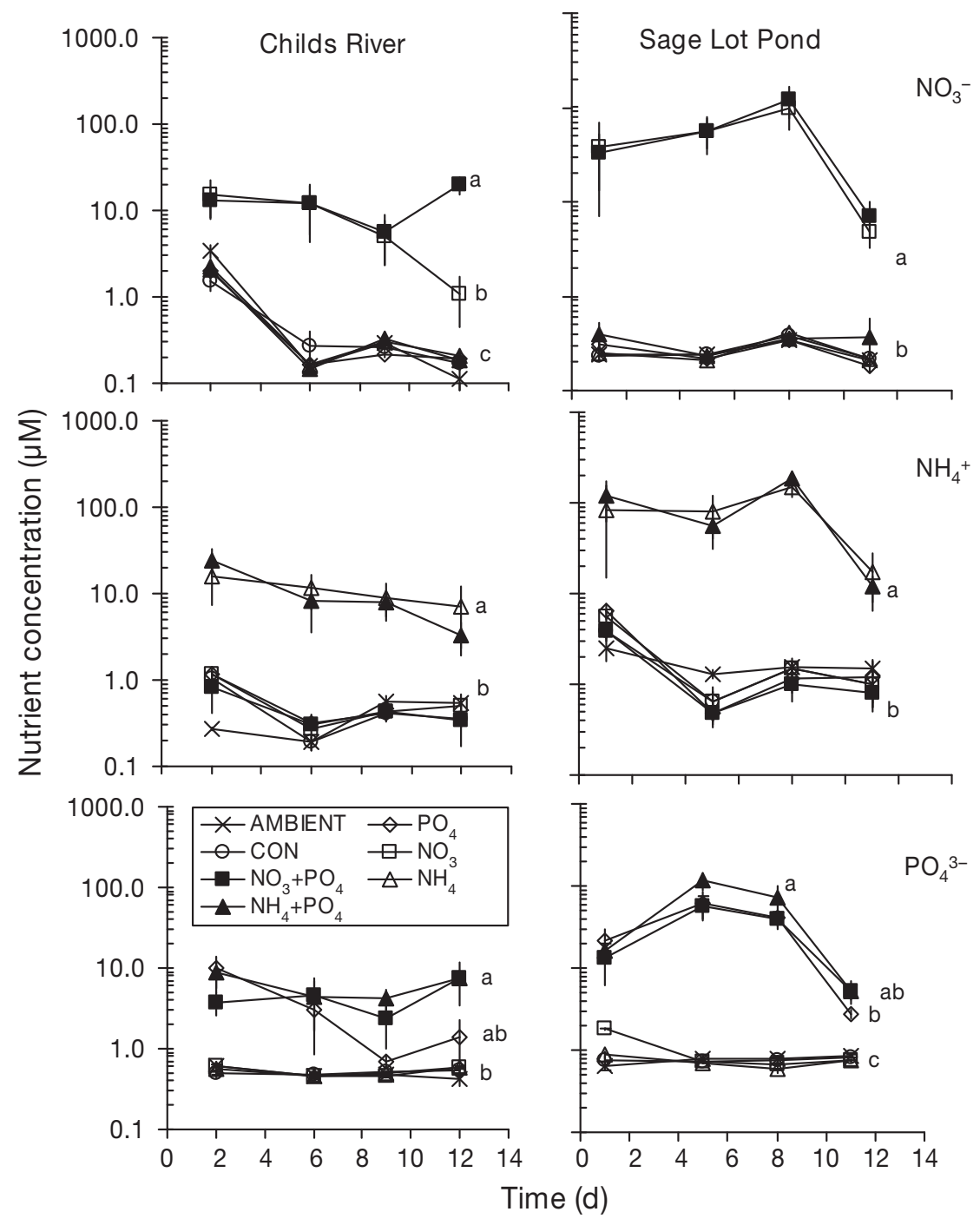

Fig. 1. Ambient and experimental concentrations of $\mathrm{NO}_{3}{ }^{-}$(top panels), $\mathrm{NH}_{4}{ }^{+}$(middle panels) and $\mathrm{PO}_{4}{ }^{3-}$ (lower panels) in Childs River and Sage Lot Pond. Means \pm $\mathrm{SE}(\mathrm{n}=4)$ for each nutrient treatment across the time of the incubation period. Lower case letters indicate treatments significantly differing in nutrient concentrations (repeated measures ANOVA, post hoc Tukey test, $\mathrm{p}<0.05$ ). CON: control

\section{RESULTS AND DISCUSSION}

\section{Nutrient concentrations in experimental treatments and ambient water}

The nutrient treatments were successful in creating different ranges of concentrations of the manipulated nutrients, and maintained these differences during the experiment (Fig. 1, Tables 1 \& 2). There were significant differences among treatments in which $\mathrm{NO}_{3}{ }^{-}, \mathrm{NH}_{4}{ }^{+}$, or $\mathrm{PO}_{4}{ }^{3-}$, or a combination of $\mathrm{N}$ and $\mathrm{P}$ were added, with an order of magnitude or higher concentration of the added nutrients compared to ambient concentrations and other nutrient treatments (Fig. 1, Table 2). Although the concentrations of the nutrients in enriched treatments varied across time and between sites (Fig. 1, Table 1), the values were consistently in excess of ambient concentrations in both estuaries across the incubation period (Table 2) and higher than the natural range known to saturate growth rates of Ulva and Gracilaria spp. in control cultures (DeBoer et al. 1978, Lapointe \& Tenore 1981).

The ambient nutrient concentrations varied between the 2 estuaries (Table 2). Mean $\mathrm{NO}_{3}{ }^{-}$concentration was higher in $\mathrm{CR}$, while mean $\mathrm{NH}_{4}{ }^{+}$ and $\mathrm{PO}_{4}{ }^{3-}$ concentrations were higher in SLP. Ambient DIN:PO $\mathrm{PO}_{4}$ was low in both sites; they were similar to ratios common in temperate coastal waters 
Table 1. Repeated measures ANOVA with $\mathrm{NO}_{3}{ }^{-}, \mathrm{NH}_{4}{ }^{+}$, and $\mathrm{PO}_{4}{ }^{3-}$ concentrations from Childs River and Sage Lot Pond as dependent variables, time as the within-subject factor, and nutrient treatment as the between-subject factor. Significant differences in bold $(p<0.05)$

\begin{tabular}{|c|c|c|c|c|}
\hline \multicolumn{2}{|c|}{$\begin{array}{l}\text { Dependent variable } \\
\text { concentration }\end{array}$} & $\mathrm{df}$ & $F$ & $\mathrm{p}$ \\
\hline \multicolumn{5}{|c|}{ Childs River } \\
\hline \multirow[t]{3}{*}{$\mathrm{NO}_{3}^{-}$} & Time & 3 & 3.1 & 0.04 \\
\hline & Nutrient & 6 & 18.7 & $<0.001$ \\
\hline & Time $\times$ Nutrient & 18 & 1.5 & 0.14 \\
\hline \multirow{3}{*}{$\mathrm{NH}_{4}^{+}$} & Time & 3 & 2.8 & 0.05 \\
\hline & Nutrient & 6 & 14.2 & $<0.001$ \\
\hline & Time $\times$ Nutrient & 18 & 1.4 & 0.16 \\
\hline \multirow[t]{3}{*}{$\mathrm{PO}_{4}{ }^{3-}$} & Time & 3 & 2.5 & 0.07 \\
\hline & Nutrient & 6 & 8.8 & $<0.001$ \\
\hline & Time $\times$ Nutrient & 18 & 1.6 & 0.08 \\
\hline \multicolumn{5}{|c|}{ Sage Lot Pond } \\
\hline \multirow[t]{3}{*}{$\mathrm{NO}_{3}^{-}$} & Time & 3 & 8.1 & $<0.001$ \\
\hline & Nutrient & 6 & 8.0 & $<0.001$ \\
\hline & Time $\times$ Nutrient & 18 & 3.7 & $<0.001$ \\
\hline \multirow[t]{3}{*}{$\mathrm{NH}_{4}^{+}$} & Time & 3 & 6.4 & 0.001 \\
\hline & Nutrient & 6 & 31.7 & $<0.001$ \\
\hline & Time $\times$ Nutrient & 18 & 2.9 & 0.001 \\
\hline \multirow[t]{3}{*}{$\mathrm{PO}_{4}^{-3}$} & Time & 3 & 20.2 & $<0.001$ \\
\hline & Nutrient & 6 & 13.0 & $<0.001$ \\
\hline & Time $\times$ Nutrient & 18 & 8.1 & $<0.001$ \\
\hline
\end{tabular}

and lower than those in tropical, carbonate-rich coastal waters (Lapointe et al. 1992). The $\mathrm{NO}_{3}{ }^{-}$concentration during the incubation period, however, did not reflect the annual mean concentration of $\mathrm{NO}_{3}{ }^{-}$in $\mathrm{CR}$, which is actually much higher $(14 \mu \mathrm{M}$, Holmes 2008) due to high inputs of wastewater entering the estuary through the groundwater (Valiela et al. 1997b). The uptake of DIN by phytoplankton and macroalgae during summer when biomasses are high is thought to be the main cause of lower DIN concentrations during this season. Therefore, we hypothesized that macroalgae from CR and SLP would be primarily $\mathrm{N}$-limited during the summer period when competition for nutrients is high.

The ranges in light intensity reaching the sediment ( $0.7 \mathrm{~m}$ depth) and temperature were similar between sites (Table 2). Dissolved oxygen and salinity were slightly higher in SLP than in CR. These water column measurements for CR and SLP were similar to those taken in July 2002 in previous surveys (Holmes 2008).

\section{Response of macroalgae to nutrient enrichment}

Growth

The macroalgal growth response to nutrient enrichment varied by species, site, and nutrient treatment (Fig. 2, Table 3). Growth rates of Ulva lactuca (6 to $16 \%$ $\mathrm{d}^{-1}$ ) were higher overall than those of Gracilaria tikvahiae (4 to $10 \% \mathrm{~d}^{-1}$ ) (Fig. 2). Growth of U. lactuca in controls was higher in CR than in SLP, and increased with $\mathrm{N}$ enrichment in SLP (Fig. 2) when either $\mathrm{NO}_{3}{ }^{-}$or $\mathrm{NH}_{4}{ }^{+}$was added. Growth of G. tikvahiae was higher overall in SLP (Fig. 2), and did not respond significantly to $\mathrm{N}$ enrichment in either site, although growth tended to be higher in the $\mathrm{NH}_{4}{ }^{+}$enrichments in SLP (Fig. 2). Neither species responded to $\mathrm{PO}_{4}{ }^{3-}$ enrichment, and did not increase growth with $\mathrm{N}+\mathrm{P}$ enrichment (relative to $\mathrm{N}$ enrichment) (Fig. 2). Hence, the macroalgae were primarily N-limited, with no signs of P-limitation during the experiment, as suggested by ambient nutrient concentrations and the results of other studies in temperate estuaries (Howarth 1988, Pedersen \& Borum 1996).

There were species-specific differences in growth rate response to DIN, and Ulva lactuca may be more Nlimited in oligotrophic conditions where it responds to supply of both forms of DIN; Gracilaria tikvahiae has lower growth rates and may be less N-limited than $U$. lactuca. Earlier Ulva and Gracilaria spp. growth studies support these findings (DeBoer et al. 1978, Lapointe \&

Table 2. Ambient nutrient concentrations, DIN: $\mathrm{PO}_{4}{ }^{3-}$, and nutrient concentrations in experimental treatments (means $\pm \mathrm{SE}_{\text {; }}$ nutrient enrichment order of magnitude relative to ambient nutrient concentrations in parentheses), range in light intensity at the sediment surface, temperature, dissolved oxygen, and salinity (means $\pm \mathrm{SE}$ ) measured during the experimental incubations in Childs River (CR) and Sage Lot Pond (SLP) during July 2005

\begin{tabular}{|c|c|c|}
\hline Variable & $\mathrm{CR}$ & SLP \\
\hline \multicolumn{3}{|c|}{ Ambient nutrient concentration $(\mu \mathrm{M})$} \\
\hline $\mathrm{NO}_{3}^{-}$ & $0.99 \pm 0.45$ & $0.26 \pm 0.02$ \\
\hline $\mathrm{NH}_{4}^{+}$ & $0.39 \pm 0.06$ & $1.71 \pm 0.21$ \\
\hline $\mathrm{PO}_{4}^{3-}$ & $0.49 \pm 0.03$ & $0.77 \pm 0.03$ \\
\hline $\mathrm{DIN}: \mathrm{PO}_{4}{ }^{3-}$ & $2.5 \pm 1.4$ & $2.7 \pm 0.6$ \\
\hline \multicolumn{3}{|c|}{ Experimental nutrient concentration $(\mu \mathrm{M})$} \\
\hline $\mathrm{NO}_{3}{ }^{-}$in all $\mathrm{NO}_{3}^{-}$treatments & $10.6 \pm 2.3(11)$ & $51.8 \pm 15.6(200)$ \\
\hline $\mathrm{NH}_{4}^{+}$in all $\mathrm{NH}_{4}^{+}$treatments & $11.0 \pm 2.5(28)$ & $88.1 \pm 23.4(51)$ \\
\hline $\mathrm{PO}_{4}{ }^{3-}$ in all $\mathrm{PO}_{4}{ }^{3-}$ treatments & $4.8 \pm 0.9(10)$ & $37.5 \pm 10.3(48)$ \\
\hline \multicolumn{3}{|c|}{ Light intensity at sediment surface ( $\sim .7 \mathrm{~m}$ depth) } \\
\hline$\left(\mu \mathrm{mol}\right.$ photons $\left.\mathrm{s}^{-1} \mathrm{~m}^{-2}\right)$ & $304-712$ & $274-704$ \\
\hline Temperature $\left({ }^{\circ} \mathrm{C}\right)$ & $26.2 \pm 0.2$ & $25.4 \pm 1.0$ \\
\hline Dissolved oxygen $\left(\mathrm{mg} \mathrm{l}^{-1}\right)^{\mathrm{a}}$ & $5.2 \pm 0.4$ & $7.5 \pm 0.2$ \\
\hline Salinity (ppt) & $23.6 \pm 0.6$ & $28.0 \pm 0.2$ \\
\hline
\end{tabular}


Tenore 1981). Species-specific differences in growth response to $\mathrm{N}$ may also depend on the prior nutrient history of the fronds, the long-term ambient nutrient supply, and differences in nutrient storage capacity, as found in previous studies (DeBoer et al. 1978, Peckol et al. 1994, Aguiar et al. 2003, Fong et al. 2003).

\section{Internal nutrient pools}

Internal tissue $\mathrm{N}$ content differed among species, site, and nutrient treatment (Fig. 3, Table 3). Initial \% tissue $\mathrm{N}$ of Ulva lactuca was higher in CR than in SLP (Fig. 3), while Gracilaria tikvahiae showed the reverse trend (Fig. 3), indicating that U. lactuca was N-replete in CR and G. tikvahiae was N-replete in SLP at the start of the incubations. After the incubations, final \% tissue $\mathrm{N}$ in both species and estuaries was lowest in controls and $\mathrm{PO}_{4}{ }^{3-}$ treatments, often lower than initial values (Fig. 3). When $\mathrm{N}$ was added, either as $\mathrm{NO}_{3}{ }^{-}$or $\mathrm{NH}_{4}{ }^{+}$, final \% tissue $\mathrm{N}$ was significantly higher in both species. In $U$. lactuca and in G. tikvahiae, the final \% tissue $\mathrm{N}$ in $\mathrm{NH}_{4}{ }^{+}$treatments was often higher than in $\mathrm{NO}_{3}{ }^{-}$treatments, particularly in SLP. Overall percent tissue $\mathrm{N}$ of $U$. lactuca did not differ by $\mathrm{NO}_{3}{ }^{-}$or $\mathrm{NH}_{4}{ }^{+}$ concentration (Fig. 3). This indicates there were similar uptakes of both forms of N. The affinity of G. tikvahiae for $\mathrm{NH}_{4}{ }^{+}$is shown by the significantly higher final \% $\mathrm{N}$ in the fronds when $\mathrm{NH}_{4}{ }^{+}$and $\mathrm{PO}_{4}{ }^{3-}$ were added (Fig. 3). Uptake of $\mathrm{NO}_{3}{ }^{-}$is inhibited by $\mathrm{NH}_{4}{ }^{+}$concentrations above $5 \mu \mathrm{M}$, and by a rate-saturation mechanism in $G$. gracilis (Smit 2002). Therefore, periodic high ambient $\mathrm{NH}_{4}{ }^{+}$concentrations found in SLP, or $\mathrm{NO}_{3}{ }^{-}$saturation may explain the higher final \% tissue $\mathrm{N}$ in G. tikvahiae fronds enriched with $\mathrm{NH}_{4}{ }^{+}$relative to $\mathrm{NO}_{3}{ }^{-}$enrichment.

The lower \% tissue $\mathrm{N}$ in control cages compared to initial levels may be due to several factors, including low ambient DIN concentrations during the experiment, fast growth rates leading to a decrease in \% tissue $\mathrm{N}$ due to dilution (as stored $\mathrm{N}$ is being used for growth), or caging effects that may reduce flow and uptake of ambient DIN. Ancillary experiments with open cages during the time of the experiments showed a similar loss in \% tissue $\mathrm{N}$ (data not shown). Therefore, we believe the first 2 factors were responsible for the loss in \% tissue $\mathrm{N}$, which we have discussed more thoroughly in another study (Teichberg et al. 2007).
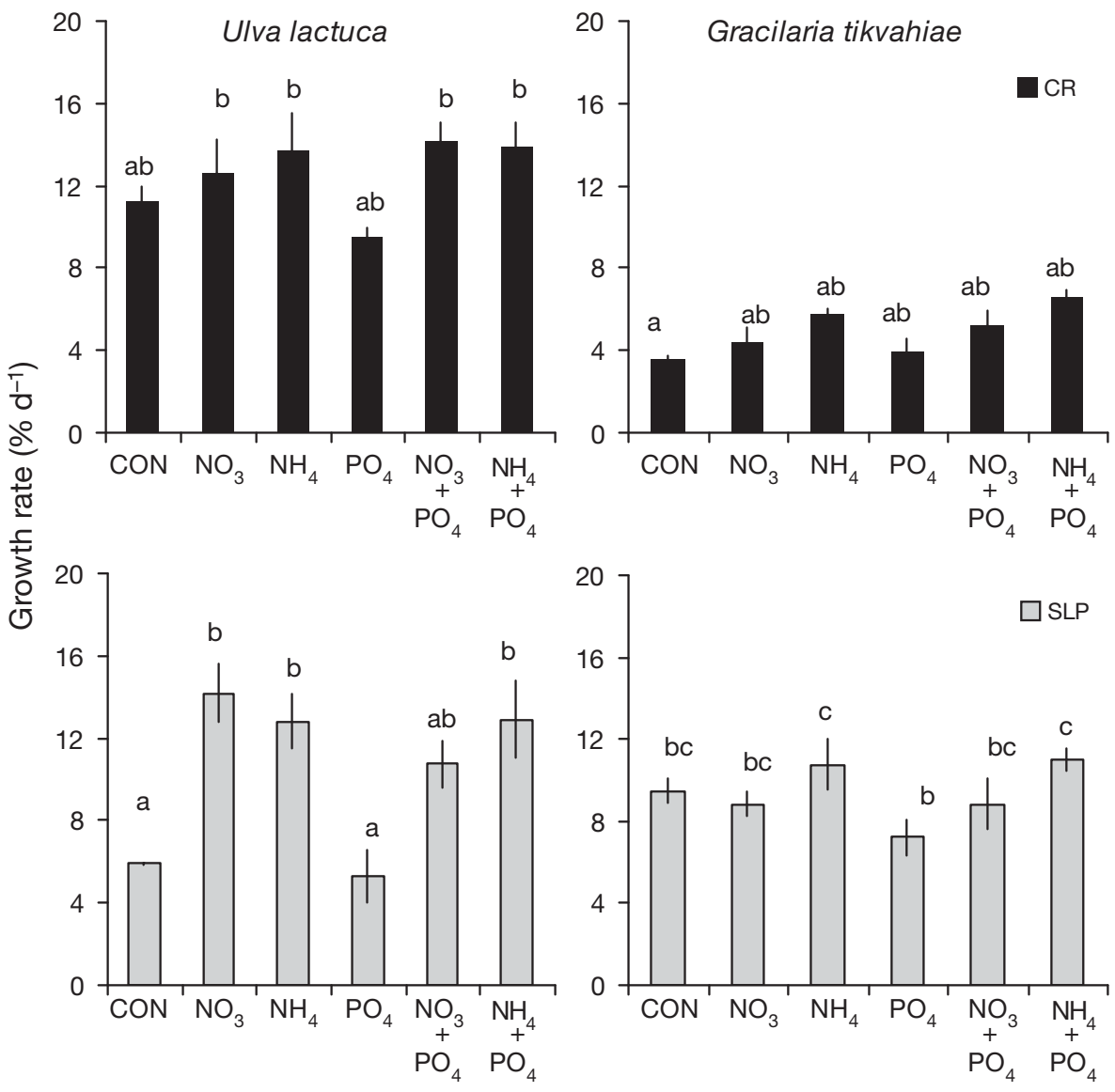

Nutrient treatment

Fig. 2. Ulva lactuca and Gracilaria tikvahiae. Growth rate $\left(\begin{array}{ll}\% & d^{-1}\end{array}\right)$ responses to nutrient enrichment treatments in $\mathrm{CR}$ (top) and SLP (bottom). See 'Materials and methods' for treatment details. Common lower case letters identify statistically homogenous groups (post-hoc Tukey tests between nutrient treatments within a species, $\mathrm{p}<0.05$ ). Values are means $\pm \mathrm{SE}$, $\mathrm{n}=4$. CR: Childs River, SLP: Sage Lot Pond, CON: control 
Table 3. Ulva lactuca and Gracilaria tikvahiae. Nested ANOVA of growth rates, final \% tissue $\mathrm{N}$, tissue C:N, and $\delta^{15} \mathrm{~N}$ signatures of fronds, with nutrient treatment nested in site. Significant differences in bold $(p<0.05)$

\begin{tabular}{|c|c|c|c|c|}
\hline \multicolumn{2}{|c|}{ Dependent variable } & $\mathrm{df}$ & $F$ & $\mathrm{p}$ \\
\hline \multicolumn{5}{|c|}{ Growth rate ( $\%$ growth $\mathrm{d}^{-1}$ ) } \\
\hline \multirow[t]{2}{*}{ U. lactuca } & Site & 1 & 11.3 & 0.002 \\
\hline & Nutrient (Site) & 10 & 6.6 & $<0.001$ \\
\hline \multirow[t]{2}{*}{ G. tikvahiae } & Site & 1 & 140 & $<0.001$ \\
\hline & Nutrient (Site) & 10 & 4.0 & 0.001 \\
\hline \multicolumn{5}{|c|}{ Final \% tissue $\mathrm{N}$} \\
\hline \multirow[t]{2}{*}{ U. lactuca } & Site & 1 & 10.1 & 0.003 \\
\hline & Nutrient (Site) & 10 & 22 & $<0.001$ \\
\hline \multirow[t]{2}{*}{ G. tikvahiae } & Site & 1 & 11.3 & 0.002 \\
\hline & Nutrient (Site) & 10 & 27 & $<0.001$ \\
\hline \multicolumn{5}{|l|}{ Tissue C:N } \\
\hline \multirow{2}{*}{ U. lactuca } & Site & 1 & 0.75 & 0.4 \\
\hline & Nutrient (Site) & 10 & 31 & $<0.001$ \\
\hline \multirow[t]{2}{*}{ G. tikvahiae } & Site & 1 & 9.3 & 0.004 \\
\hline & Nutrient (Site) & 10 & 43 & $<0.001$ \\
\hline \multicolumn{5}{|l|}{$\delta^{15} \mathrm{~N}$ of fronds } \\
\hline \multirow[t]{2}{*}{ U. lactuca } & Site & 1 & 295 & $<0.001$ \\
\hline & Nutrient (Site) & 10 & 33 & $<0.001$ \\
\hline \multirow[t]{2}{*}{ G. tikvahiae } & Site & 1 & 291 & $<0.001$ \\
\hline & Nutrient (Site) & 10 & 54 & $<0.001$ \\
\hline
\end{tabular}

The $\mathrm{C}: \mathrm{N}$ of the macroalgal fronds differed among species, sites, and nutrient treatments (Fig. 3, Table 3). Ulva lactuca had a higher initial C:N in SLP than in CR (Fig. 3), which is a further indication that this species was initially more N-starved in SLP. Gracilaria tikvahiae, in contrast, had a higher initial C: $N$ in CR than in SLP (Fig. 3), showing that this species was more $\mathrm{N}$-starved in CR. After experimental enrichment, the $\mathrm{C}: \mathrm{N}$ significantly increased in control and $\mathrm{PO}_{4}{ }^{3-}$ treatments compared to initial values, while the C:N was significantly lower in $\mathrm{NO}_{3}{ }^{-}$and $\mathrm{NH}_{4}{ }^{+}$treatments (Fig. 3, Table 3). The higher $\mathrm{C}: \mathrm{N}$ in $U$. lactuca may be explained by the increase in tissue $\mathrm{C}$ as the fronds grew and consumed internal $\mathrm{N}$ pools. In contrast, algal fronds enriched with $\mathrm{NO}_{3}{ }^{-}$and $\mathrm{NH}_{4}{ }^{+}$maintained high internal $\mathrm{N}$ pools even at high growth rates, as shown by lower $C: N$. Overall, however, $C: N$ of the thalli was similar to that found in these and other macroalgal species from different geographical locations (Lapointe et al. 1992) under varying conditions. In U. fasciata, high irradiance and carbohydrate storage have been shown to increase C:N, while high $\mathrm{N}$ supply decreases C:N (Lapointe \& Tenore 1981). In G. tikvahiae, a $\mathrm{C}: \mathrm{N}$ of 13 was observed in fronds growing at high rates (Lapointe 1981) similar to those we observed in SLP. The lower C:N in G. tikvahiae may be explained by the high $\mathrm{N}$ storage capacity of this species (Fujita 1985).

\section{$\delta^{15} \mathrm{~N}$ response to $\mathrm{NO}_{3}{ }^{-}$and $\mathrm{NH}_{4}{ }^{+}$treatments}

We compared the $\delta^{15} \mathrm{~N}$ signatures of fronds in different treatments (Fig. 3); those of both species at both sites were lighter in the $\mathrm{NO}_{3}{ }^{-}$and $\mathrm{NH}_{4}{ }^{+}$and combined $\mathrm{N}$ and $\mathrm{P}$ enrichments (Fig. 3). The $\delta^{15} \mathrm{~N}$ signatures from CR were originally heavier than those from SLP due to the greater input of wastewater in this site, and hence heavier $\delta^{15} \mathrm{~N}$ (McClelland \& Valiela 1998). The $\delta^{15} \mathrm{~N}$ of fertilizers used in our enrichments were $-2.8 \%$ and $-0.6 \%$ for $\mathrm{NO}_{3}{ }^{-}$and $\mathrm{NH}_{4}{ }^{+}$, respectively, values that are relatively light compared to the source of ambient DIN in the 2 estuaries. The decrease in the $\delta^{15} \mathrm{~N}$ signatures in fronds enriched with $\mathrm{NO}_{3}{ }^{-}$and $\mathrm{NH}_{4}{ }^{+}$is a reflection of the change in internal $\mathrm{N}$ pools within fronds as ambient DIN was replaced by fertilizer N. In an earlier study, we found that this change in U. lactuca took place over 2 to $5 \mathrm{~d}$ (Teichberg et al. 2007). The lighter $\delta^{15} \mathrm{~N}$ signatures indicate rapid assimilation of the fertilizer source by the end of the incubation period.

The greater decrease in $\delta^{15} \mathrm{~N}$ values occurred in response to $\mathrm{NH}_{4}^{+}$in both seaweed species (Fig. 3), despite the slightly heavier $\delta^{15} \mathrm{~N}$ of the $\mathrm{NH}_{4}{ }^{+}$fertilizer $(-0.6 \%)$ than the $\mathrm{NO}_{3}{ }^{-}$fertilizer $(-2.8 \%$ o). Uptake of $\mathrm{NH}_{4}{ }^{+}$allowed a closer convergence to fertilizer $\delta^{15} \mathrm{~N}$, which suggests affinity for $\mathrm{NH}_{4}{ }^{+}$rather than $\mathrm{NO}_{3}{ }^{-}$in both species, and indicates that both may assimilate $\mathrm{NH}_{4}{ }^{+}$faster than $\mathrm{NO}_{3}{ }^{-}$. Similar results have been found in laboratory incubation experiments with Ulva fenestrata, Gracilaria pacifica (Naldi \& Wheeler 2002), and $U$. intestinalis (Cohen \& Fong 2004, 2005) in which a labeled source of ${ }^{15} \mathrm{NH}_{4}{ }^{+}$was incorporated faster than ${ }^{15} \mathrm{NO}_{3}{ }^{-}$. The lighter $\delta^{15} \mathrm{~N}$ values of algal fronds with $\mathrm{NH}_{4}{ }^{+}$enrichment (relative to the $\delta^{15} \mathrm{~N}$ signature of the $\mathrm{NH}_{4}{ }^{+}$fertilizer in SLP) in our experiments suggest that isotopic fractionation was small (approximately 0 to -1.5), assuming that all $\mathrm{N}$ turnover was complete, and all new internal $\mathrm{N}$ is from the $\mathrm{NH}_{4}{ }^{+}$fertilizer. Longer incubation times will be necessary to determine isotopic fractionation during $\mathrm{NO}_{3}^{-}$uptake since $\mathrm{NO}_{3}^{-}$ turnover seems to be slower than for $\mathrm{NH}_{4}{ }^{+}$.

\section{Comparison of macroalgal responses to availability of $\mathrm{NO}_{3}{ }^{-}$versus $\mathrm{NH}_{4}{ }^{+}$}

Ulva lactuca responded quickly to both forms of DIN, as shown by the increased growth, high \% tissue $\mathrm{N}$, and lower $\delta^{15} \mathrm{~N}$ values with $\mathrm{NO}_{3}{ }^{-}$or $\mathrm{NH}_{4}{ }^{+}$enrichment. The growth response increase was more pronounced in SLP, the site where ambient growth rates of this species were lower, and where annual DIN concentrations were relatively low. In fact, most reported macroalgal blooms suggest a similar trend. For example, Ulva spp. blooms have been found in highly eutrophic waters 

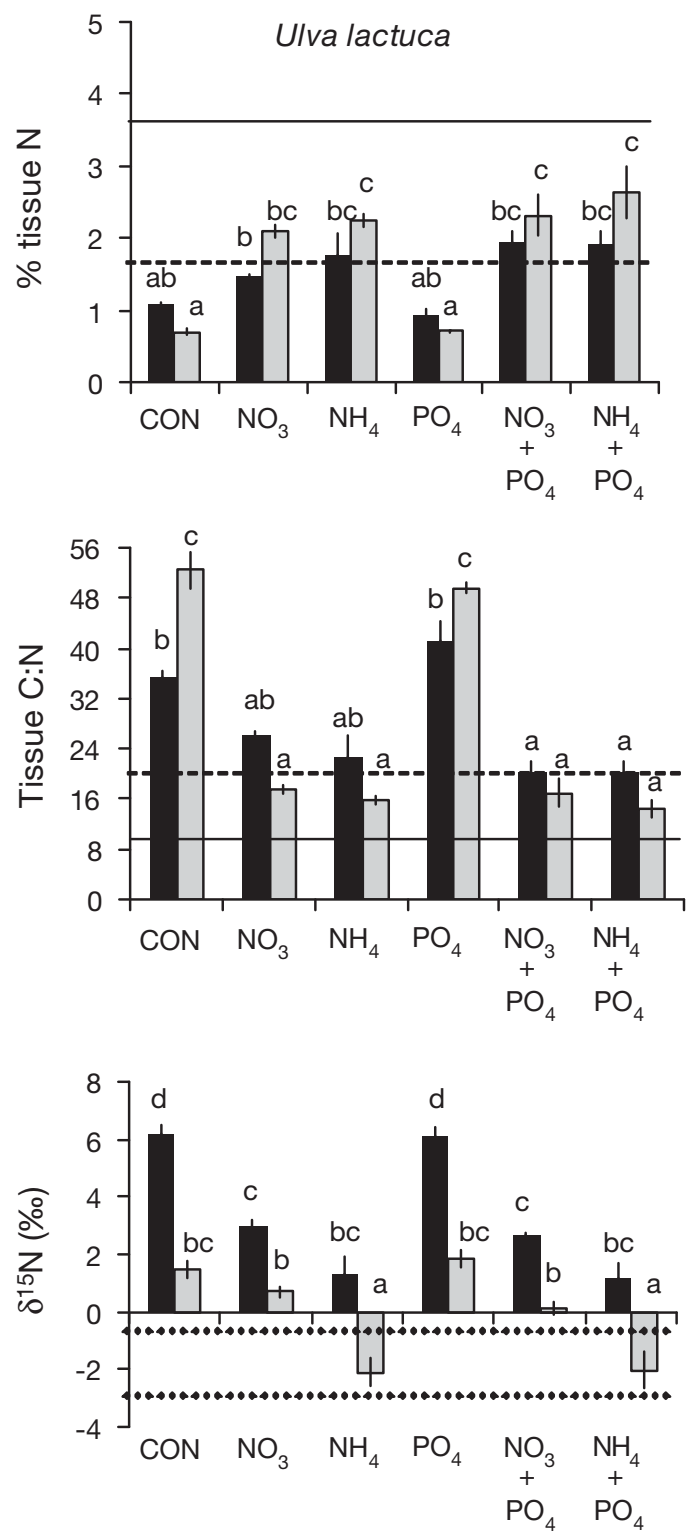
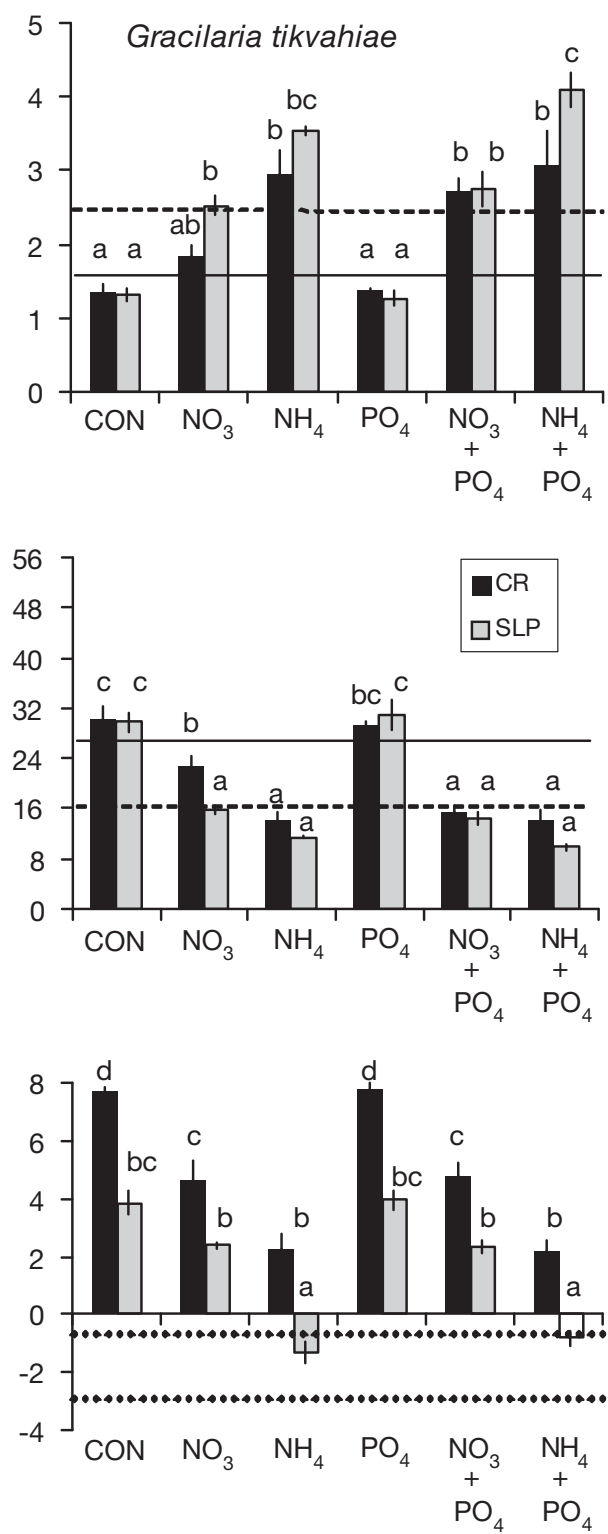

Nutrient treatment

Fig. 3. Ulva lactuca and Gracilaria tikvahiae. Final \% tissue N, tissue C:N, and $\delta^{15} \mathrm{~N}$ signatures of fronds in response to nutrient enrichment in CR (Childs River) and SLP (Sage Lot Pond). See 'Materials and methods' for treatment details. Black line and dashed line in middle and upper panels indicate initial values in CR and SLP respectively. Dotted lines in lower panels indicate $\delta^{15} \mathrm{~N}$ values of the $\mathrm{NH}_{4}{ }^{+}(-0.6 \%)$ and $\mathrm{NO}_{3}^{-}(-2.8 \%$ o) fertilizers. Common lower case letters identify statistically homogenous groups (post-hoc Tukey test between nutrient treatments within a species, $\mathrm{p}<0.05)$. Values are means $\pm \mathrm{SE}, \mathrm{n}=4$. CON: control

with high water column $\mathrm{NO}_{3}{ }^{-}$and $\mathrm{NH}_{4}{ }^{+}$concentrations derived from sewage and fertilizers, such as those of Venice Lagoon and Sacca di Goro, Italy (Sfriso et al. 1992, Naldi \& Viaroli 2002), upper Newport Bay estuary, California, USA (Kamer et al. 2001), and Port Phillip Bay, Australia (Campbell 2001).

In contrast, Gracilaria tikvahiae did not significantly increase growth in response to $\mathrm{NO}_{3}{ }^{-}$or $\mathrm{NH}_{4}{ }^{+}$enrichment in either site, but there were increases in \% $\mathrm{N}$ and greater decreases in $\delta^{15} \mathrm{~N}$ values with $\mathrm{NH}_{4}{ }^{+}$than with $\mathrm{NO}_{3}{ }^{-}$enrichment. The lack of growth response to $\mathrm{N}$, particularly to $\mathrm{NH}_{4}{ }^{+}$enrichment, was surprising, as we had hypothesized that the high biomass of G. tikvahiae in SLP and high ambient growth rates may be due to high summer $\mathrm{NH}_{4}{ }^{+}$concentrations in this site (Fox 2008), and higher affinity for $\mathrm{NH}_{4}{ }^{+}$in G. tikvahiae. Gracilaria spp. blooms have been found in areas where concentrations of $\mathrm{NH}_{4}{ }^{+}$in the water column are ele- 
vated by sewage, aquaculture waste, or internal nitrogen sources from benthic cycling, such as in Nanwan Bay, Taiwan (Tsai et al. 2005), the east central coast of Florida, USA (Barile 2004), southwest Florida, USA (Lapointe \& Bedford 2007), Thau Lagoon in southern France (De Casabianca et al. 1997), and Hogs Island Bay, Virginia, USA (Tyler et al. 2001). Despite the lack of growth response in G. tikvahiae to $\mathrm{N}$ enrichment, the high \% tissue $\mathrm{N}$ and lower $\delta^{15} \mathrm{~N}$ values indicated that uptake of the $\mathrm{NO}_{3}{ }^{-}$and $\mathrm{NH}_{4}{ }^{+}$fertilizer did occur. This suggests that uptake and assimilation of DIN are uncoupled from growth in G. tikvahiae, which is not the case in Ulva lactuca.

Our experiments indicate that growth of Ulva spp. in $\mathrm{N}$-limited systems is likely to increase under high water column concentrations of either $\mathrm{NO}_{3}^{-}$or $\mathrm{NH}_{4}^{+}$ (although the thalli have higher affinity for $\mathrm{NH}_{4}^{+}$). Gracilaria spp. may require less $\mathrm{N}$ to sustain growth, but may not be able to compete with Ulva spp. which have faster growth rates under high DIN concentrations. However, it is not clear what role interspecific competition for nutrients, light, and space plays in controlling the dynamics of macroalgal blooms. In Waquoit Bay, the high growth rates of U. lactuca and its ability to grow quickly under both $\mathrm{NO}_{3}{ }^{-}$and $\mathrm{NH}_{4}{ }^{+}$ supply may give it an advantage over G. tikvahiae. Therefore, increases in biomass of U. lactuca during the summer may affect growth of G. tikvahiae in CR. In contrast, the biomass of U. lactuca in SLP remains low, and $G$. tikvahiae can take advantage of high availability of $\mathrm{NH}_{4}{ }^{+}$in the late summer. To better understand the bloom dynamics of these 2 species, more studies on their direct competition for light and nutrients are required.

Acknowledgements. We thank the following funding sources for supporting this research: NOS/ECOHAB grant \#NA16OP2728, Palmer McCleod Fellowship awarded to M.T., NOAA/NERRS and EPA STAR graduate fellowships awarded to S.E.F., and NSF REU support awarded to C.A. This is ECOHAB publication \#214. Thanks to A. Giblin, L. Mullineaux, and anonymous reviewers for thoughtful comments on earlier drafts of this manuscript.

\section{LITERATURE CITED}

Aguiar AB, Morgan JA, Teichberg M, Fox S, Valiela I (2003) Transplantation and isotopic evidence of the relative effects of ambient and internal nutrient supply on the growth of Ulva lactuca. Biol Bull 205:250-251

Barile PJ (2004) Evidence of anthropogenic nitrogen enrichment of the littoral waters of east central Florida. J Coast Res 20:1237-1245

Campbell S (2001) Ammonium requirements of fast-growing ephemeral macroalgae in a nutrient-enriched marine embayment (Port Phillip Bay, Australia). Mar Ecol Prog Ser 209:99-107

Cloern JE (2001) Our evolving conceptual model of the coastal eutrophication problem. Mar Ecol Prog Ser 210: 223-253

Cohen RA, Fong P (2004) Nitrogen uptake and assimilation in Enteromorpha intestinalis (L.) Link (Chlorophyta): using ${ }^{15} \mathrm{~N}$ to determine preference during simultaneous pulses of nitrate and ammonium. J Exp Mar Biol Ecol 309:67-77

Cohen RA, Fong P (2005) Experimental evidence supports the use of $\delta^{15} \mathrm{~N}$ content of the opportunistic green macroalga Enteromorpha intestinalis (Chlorophyta) to determine nitrogen sources to estuaries. J Phycol 41:287-293

> DeBoer JA, Guigli HJ, Israel TL, D'Elia CF (1978) Nutritional studies of two red algae. I. Growth rate as a function of nitrogen source and concentration. J Phycol 14:261-266

$>$ De Casabianca ML, Laugier T, Marinho-Soriano E (1997) Seasonal changes of nutrients in water and sediment in a Mediterranean lagoon with shellfish farming activity (Thau Lagoon, France). ICES J Mar Sci 54:905-916

D'Elia CF, DeBoer JA (1978) Nutritional studies of two red algae. II. Kinetics of ammonium and nitrate uptake. J Phycol 14:266-272

> Deutsch B, Voss M (2006) Anthropogenic nitrogen input traced by means of $\delta^{15} \mathrm{~N}$ values in macroalgae: results from in-situ incubation experiments. Sci Total Environ 366: 799-808

Duarte CM (1995) Submerged aquatic vegetation in relation to different nutrient regimes. Ophelia 41:87-112

> Duke CS, Litaker W, Ramus J (1989) Effects of temperature, nitrogen supply, and tissue nitrogen on ammonium uptake rates of the chlorophyte seaweeds Ulva curvata and Codium decorticatum. J Phycol 25:113-120

Fong P, Boyer KE, Kamer K, Boyle KA (2003) Influence of initial tissue nutrient status of tropical marine algae on response to nitrogen and phosphorus additions. Mar Ecol Prog Ser 262:111-123

Fong P, Fong JJ, Fong CR (2004) Growth, nutrient storage, and release of dissolved organic nitrogen by Enteromorpha intestinalis in response to pulses of nitrogen and phosphorus. Aquat Bot 78:83-95

Fox SE (2008) Ecological effects of nitrogen loading to temperate estuaries: macrophyte and consumer community structure and food web relationships. PhD thesis, Boston University, Boston, MA

Fox SE, Stieve E, Valiela I, Hauxwell J, McClelland J (2008) Macrophyte abundance in Waquoit Bay: effects of landderived nitrogen loads on seasonal and multi-year biomass patterns. Estuaries Coasts 31:532-541

Fujita RM (1985) The role of nitrogen status in regulating transient ammonium uptake and nitrogen storage by macroalgae. J Exp Mar Biol Ecol 92:283-301

Holmes GT (2008) Nutrient supply, water residence time, temperature, and grazing as controls of size-fractioned phytoplankton biomass in shallow temperate estuarine ecosystems. PhD thesis, Boston University, Boston, MA

> Howarth RW (1988) Nutrient limitation of net primary production in marine ecosystems. Annu Rev Ecol Syst 19:89-110

Howarth R, Sharpley A, Walker D (2002) Sources of nutrient pollution to coastal waters in the United States: implications for achieving coastal water quality goals. Estuaries 25:656-676

Kamer K, Boyle KA, Fong P (2001) Macroalgal bloom dynamics in a highly eutrophic southern California estuary. Estuaries 24:623-635

Lapointe BE (1981) The effects of light and nitrogen on growth, pigment content, and biochemical composition of Gracilaria foliifera v. angustissima (Gigartinales, Rhodophyta). J Phycol 17:90-95

Lapointe BE, Bedford BJ (2007) Drift rhodophyte blooms 
emerge in Lee County, Florida, USA: evidence of escalating coastal eutrophication. Harmful Algae 6:421-437

Lapointe BE, Tenore KR (1981) Experimental outdoor studies with Ulva fasciata Delile. I. Interaction of light and nitrogen on nutrient uptake, growth, and biochemical composition. J Exp Mar Biol Ecol 53:135-152

- Lapointe BE, Littler MM, Littler DS (1992) Nutrient availability to marine macroalgae in siliciclastic versus carbonaterich coastal waters. Estuaries 15:75-82

Lapointe BE, Barile PJ, Littler MM, Littler DS, Bedford B, Gasque C (2005a) Macroalgal blooms on southeast Florida coral reefs. I. Nutrient stoichiometry of the invasive green alga Codium isthmocladum in the wider Caribbean indicates nutrient enrichment. Harmful Algae 4:1092-1105

Lapointe BE, Barile PJ, Littler MM, Littler DS (2005b) Macroalgal blooms on southeast Florida coral reefs II. Cross-shelf discrimination of nitrogen sources indicates widespread assimilation of sewage nitrogen. Harmful Algae 4:1106-1122

Lartigue J, Sherman TD (2005) Response of Enteromorpha sp. (Chlorophyceae) to a nitrate pulse: nitrate uptake, inorganic nitrogen storage and nitrate reductase activity. Mar Ecol Prog Ser 292:147-157

Lepoint G, Gobert S, Dauby P, Bouquegneau JM (2004) Contributions of benthic and planktonic primary producers to nitrate and ammonium uptake fluxes in a nutrient-poor shallow coastal area (Corsica, NW Mediterranean). J Exp Mar Biol Ecol 302:107-122

Littler MM, Littler DS (1980) The evolution of thallus form and survival strategies in benthic marine macroalgae: field and laboratory tests of a functional form model. Am Nat 116:25-44

Lobban CS, Harrison PJ (1994) Seaweed ecology and physiology. Cambridge University Press, New York, NY

McClelland JW, Valiela I (1998) Linking nitrogen in estuarine producers to land-derived sources. Limnol Oceanogr 43: 577-585

Morand P, Merceron M (2005) Macroalgal population and sustainability. J Coast Res 21:1009-1020

Naldi M, Viaroli P (2002) Nitrate uptake and storage in the seaweed Ulva rigida C. Agardh in relation to nitrate availability and thallus nitrate content in a eutrophic coastal lagoon (Sacca di Goro, Po River Delta, Italy). J Exp Mar Biol Ecol 269:65-83

Naldi M, Wheeler PA (2002) ${ }^{15} \mathrm{~N}$ measurements of ammonium and nitrate uptake by Ulva fenestrata (Chlorophyta) and Gracilaria pacifica (Rhodophyta): comparison of net nutrient disappearance, release of ammonium and nitrate, and ${ }^{15} \mathrm{~N}$ accumulation in algal tissue. J Phycol 38:135-144

Nixon S, Pilson M (1983) Nitrogen in estuarine and coastal marine ecosystems. In: Carpenter EJ, Capone DG (eds) Nitrogen in the marine environment. Academic Press, New York, NY, p 565-648

Peckol P, DeMeo-Anderson B, Rivers J, Valiela I, Maldonado M, Yates J (1994) Growth, nutrient-uptake capacities and tissue constituents of the macroalgae Cladophora vagabunda and Gracilaria tikvahiae related to site-specific nitrogen loading rates. Mar Biol 121:175-185

Pedersen MF, Borum J (1996) Nutrient control of algal growth

Editorial responsibility: Otto Kinne,

Oldendorf/Luhe, Germany in estuarine waters. Nutrient limitation and the importance of nitrogen requirements and nitrogen storage among phytoplankton and species of macroalgae. Mar Ecol Prog Ser 142:261-272

> Pedersen MF, Borum J (1997) Nutrient control of estuarine macroalgae: growth strategy and the balance between nitrogen requirements and uptake. Mar Ecol Prog Ser 161: 155-163

Rafaelli DG, Raven JA, Poole LJ (1998) Ecological impact of green macroalgal blooms. Oceanogr Mar Biol Annu Rev 36:97-125

Runcie JW, Ritchie RJ, Larkum AW (2003) Uptake kinetics and assimilation of inorganic nitrogen by Catenella nipae and Ulva lactuca. Aquat Bot 76:155-174

Ryther JH, Dunstan WM (1971) Nitrogen, phosphorus and eutrophication in the coastal marine environment. Science 171:1008-1013

Sfriso A, Pavoni B, Marcomini A, Orio AA (1992) Macroalgae, nutrient cycles, and pollutants in the Lagoon of Venice. Estuaries 15:517-528

Smit AJ (2002) Nitrogen uptake by Gracilaria gracilis (Rhodophyta): adaptations to a temporally variable nitrogen environment. Bot Mar 45:196-209

Sundback K, Miles A, Hulth S, Pihl L, Engstrom P, Selander E, Svenson A (2003) Importance of benthic nutrient regeneration during initiation of macroalgal blooms in shallow bays. Mar Ecol Prog Ser 246:115-126

Teichberg M, Heffner L, Fox S, Valiela I (2007) Nitrate reductase and glutamine synthetase activity, internal $\mathrm{N}$ pools, and growth of Ulva lactuca: responses to long and shortterm N supply. Mar Biol 151:1249-1259

> Trimmer M, Nedwell D, Sivyer D, Malcom S (2000) Seasonal organic mineralisation and denitrification in intertidal sediments and their relationship to the abundance of Enteromorpha sp. and Ulva sp. Mar Ecol Prog Ser 203: $67-80$

Tsai CC, Chang JS, Sheu F, Shyu YT and others (2005) Seasonal growth dynamics of Laurencia papillosa and Gracilaria coronopifolia from a highly eutrophic reef in southern Taiwan: temperature limitation and nutrient availability. J Exp Mar Biol Ecol 315:49-69

Tyler AC, McGlathery KJ, Anderson IC (2001) Macroalgae mediation of dissolved organic nitrogen fluxes in a temperate coastal lagoon. Estuar Coast Shelf Sci 53:155-168

Valiela I, Foreman K, LaMontagne M, Hersh D and others (1992) Couplings of watersheds and coastal waters: Sources and consequences of nutrient enrichment in Waquoit Bay, Massachusetts. Estuaries Coasts 15:443-457

Valiela I, McClelland J, Hauxwell J, Behr PJ, Hersh D, Foreman K (1997a) Macroalgal blooms in shallow estuaries: controls and ecophysiological and ecosystem consequences. Limnol Oceanogr 42:1105-1118

Valiela I, Collins G, Kremer J, Lajtha K and others (1997b) Nitrogen loading from coastal watersheds to receiving estuaries: new method and application. Ecol Appl 7: $358-380$

> Worm B, Reusch TBH, Lotze HK (2000) In situ nutrient enrichment: methods for marine benthic ecology. Int Rev Hydrobiol 85:359-375

Submitted: June 13, 2007; Accepted: May 5, 2008

Proofs received from author(s): September 12, 2008 